\title{
EPIDEMIOLOGY OF ACUTE LEUKAEMIA OF CHILDHOOD IN THE LIVERPOOL AREA
}

\author{
BY \\ DOROTHY MAINWARING \\ Alder Hey Children's Hospital, Liverpool
}

Aetiological factors known to influence the development of leukaemia in man include ionizing radiation and chromosomal abnormalities (Miller, 1964). Viral agents have been demonstrated in laboratory animals and although virus-like particles and mycoplasma have been found in affected marrow cells (Negroni, 1964; Grist and Fallon, 1964) attempts to show a direct causal relationship have so far been unsuccessful in man.

Epidemiological studies have become of increasing importance, and interest in the distribution has been stimulated by reports of clustering within various communities. The outbreak in one parish in Niles, Illinois, in which eight children developed the disease within 4 years, was thought to be due to an infectious cause, especially as there was an outbreak of a "rheumatic-like" illness during the same period (Heath and Hasterlik, 1963). Other reports of smaller clusterings (Wood, 1960; Pinkel and Nefzger, 1959) were more open to interpretation as being due to chance distribution, although infection could not be excluded as a contributory factor. Studies of variation in San Francisco (Mustacchi, 1965) supported the view that cases tend to occur in a non-random way referable to the presence of previous cases.

As the incidence of leukaemia in the population is very low, it is necessary to develop statistical techniques of suitable sensitivity and validity to detect clustering, if it exists, especially within communities where the overall incidence is not obviously different from that expected. Ideally the same method should be applied to as many sets of comparable data as possible. The procedure of Knox (1963), which was first used to study the epidemiology of childhood leukaemia in Northumberland and Durham (Knox, 1964) and later in Oregon (Meighan and Knox, 1965), has recently been assessed independently (David and Barton, 1966) and shown to be an effective method of revealing space-time interaction.

The object of the present study is to examine data from the large conurbation centred on the port of Liverpool where clustering was not apparent.

\section{METHOD}

The records of patients diagnosed and treated at Alder Hey Children's Hospital, Liverpool, during the period 1955-64 were examined. Records were also obtained from the Royal Liverpool Children's Hospital for all children seen there during the same period. It is unlikely that any other patients, with home addresses in any of the seven administrative areas listed in Table I, have been diagnosed without being referred to one of these children's hospitals. Examination of the annual mortality returns of the

TABLE I

INCIDENCE BY ADMINISTRATIVE AREA AND BY YEAR

\begin{tabular}{|c|c|c|c|c|c|c|c|c|c|c|c|}
\hline \multirow{2}{*}{ Administrative Area } & \multirow{2}{*}{$\begin{array}{c}\text { Total Number } \\
1955-64\end{array}$} & \multicolumn{10}{|c|}{ Number Diagnosed in Each Year } \\
\hline & & 1955 & 1956 & 1957 & 1958 & 1959 & 1960 & 1961 & 1962 & 1963 & 1964 \\
\hline $\begin{array}{l}\text { Liverpool C.B. } \\
\text { Bootle C.B. } \\
\text { Crosby M.B. } \\
\text { Huyton-with-Roby U.D. } \\
\text { Kirkby U.D. } \\
\text { Litherland U.D. } \\
\text { W. Lancs. R.D. }\end{array}$ & $\begin{array}{r}56 \\
3 \\
5 \\
3 \\
4 \\
2 \\
1\end{array}$ & $\begin{array}{l}z \\
z \\
\frac{1}{1}\end{array}$ & $\frac{6}{\frac{3}{2}}$ & $\begin{array}{l}3 \\
\frac{1}{1} \\
\frac{1}{1}\end{array}$ & $\begin{array}{l}6 \\
1 \\
= \\
=\end{array}$ & $\begin{array}{l}\frac{6}{1} \\
= \\
=\end{array}$ & $\begin{array}{l}\frac{3}{1} \\
\frac{1}{-}\end{array}$ & $\begin{array}{l}12 \\
1 \\
= \\
=\end{array}$ & $\begin{array}{l}= \\
= \\
=\end{array}$ & $\begin{array}{l}\frac{3}{z} \\
= \\
=\end{array}$ & $\begin{array}{l}\frac{4}{2} \\
1 \\
1 \\
-\end{array}$ \\
\hline Total & 74 & 8 & 11 & 6 & 7 & 7 & 4 & 13 & 6 & 3 & 9 \\
\hline
\end{tabular}


Medical Officers of Health of the various Health Authorities provided some cross check, but any patient dying in either hospital would be included in Liverpool County Borough mortality figures, whereas the home address may lie outside the city boundaries. Ten patients who were still alive on December 31, 1964, are included in this survey.

The criteria for inclusion were as follows:

(1) The onset of acute leukaemia occurred before the 15th birthday.

(2) The home address was within the area comprising Liverpool C.B., Bootle C.B., Crosby M.B., Huyton-with-Roby U.D., Kirkby U.D., Litherland U.D., and that part of West Lancashire R.D. lying between Bootle and Kirkby.

(3) The patient was diagnosed between January 1, 1955, and December 31, 1964.

The area involved is approximately 161 sq. kilometres with a total population in 1962 of 1,091,890 (Registrar General's estimates). This year has been selected arbitrarily for all estimates of population, as the 1961 National Census figures were then available for more accurate computation. The population of Liverpool was 745,230 , of whom 187,000 were estimated.to be under 15 years of age. The population at risk in the whole area, if the proportion of children may be assumed to be constant throughout the area, would have been 273,900. From the whole area there were 74 cases, 56 of them living within the Liverpool city boundaries.

The date of onset has been taken as the date on which the first relevant symptom was noticed, as recorded in the case history at the time of admission. In about one-third, no accurate date could be remembered by the parent and the middle day of the month in which symptoms began has been arbitrarily chosen. One patient was not diagnosed during life but was found to have the disease at autopsy following a road traffic accident.

The geographical data were obtained by plotting the position of the patient's home on a street map of Liverpool and neighbouring authorities, scale $4^{\prime \prime}: 1$ mile. The position was taken as the middle of the block in which the house was known to be situated. National Grid references were then read, the least significant figure representing $0.1 \mathrm{~km}$.

\section{Results}

During the 10-year period, 74 children were found to have had acute leukaemia. Taking the estimated population at risk as being 273,900 , the mean annual incidence was $2 \cdot 71$ cases per 100,000 children over the whole area. In Liverpool, with 56 cases occurring in 187,700 children, the mean annual incidence was slightly higher, 2.98 per 100,000 .
Table I gives the number of cases by year in each administrative area. Thirteen cases were diagnosed in 1961, of whom twelve lived in Liverpool, and in 1956, out of eleven cases, three lived in Crosby and two in Kirkby. In order to see whether this apparent concentration of cases in time and space was of significance, the dates of onset were first arranged seasonally, as in Table II.

TABLE II

INCIDENCE BY MONTH OF ONSET AND MONTH OF DIAGNOSIS

\begin{tabular}{l|c|c|c|c|c|c}
\hline Month & $\begin{array}{c}\text { No. of Cases } \\
\text { with Onset } \\
\text { of Symptoms }\end{array}$ & $\begin{array}{c}\text { Cases } \\
\text { Diagnosed }\end{array}$ & \multicolumn{4}{|c|}{$\begin{array}{c}\text { Time Lag } \\
\text { Between Onset and } \\
\text { Diagnosis (days) }\end{array}$} \\
\hline January & 7 & 6 & 5 & 0 & 1 & 1 \\
February & 7 & 6 & 4 & 2 & 0 & 1 \\
March & 7 & 7 & 4 & 0 & 3 & 0 \\
April & 1 & 6 & 1 & 0 & 0 & 0 \\
May & 8 & 9 & 5 & 2 & 1 & 0 \\
June & 8 & 7 & 6 & 0 & 1 & 1 \\
July & 7 & 3 & 0 & 2 & 3 & 2 \\
August & 8 & 4 & 4 & 2 & 1 & 1 \\
September & 5 & 9 & 4 & 1 & 0 & 0 \\
October & 3 & 9 & 1 & 1 & 0 & 1 \\
November & 2 & 5 & 2 & 0 & 0 & 0 \\
December & 11 & 3 & 5 & 2 & 0 & 4 \\
\hline \multicolumn{1}{c|}{ Total } & 74 & 74 & 41 & 12 & 10 & 11 \\
\hline
\end{tabular}

In the whole group there is no obvious evidence of seasonal variation, 39 cases beginning between May and October ("summer") and 35 cases between November and April ("winter"), although if the date of diagnosis were considered, one might form a false impression that more cases occur in the summer-43 cases were confirmed during the 6-months from May to October, and 33 between November and April.

The time lag between onset of symptoms and date of diagnosis has been tabulated in relation to the month of onset but there is no significant difference in the intervals seen in this series.

The cases were then divided by age, sex, and type of leukaemia. As exact typing of the more primitive leukaemias may be very difficult, all cases have been described as (a) myeloblastic, (b) lymphoblastic including undifferentiated blastic leukaemia and two cases of lymphosarcoma which underwent leukaemic transformation, or (c) monocytic. There was one case of erythroleukaemia. The diagnosis in each case was based upon clinical findings and full haematological investigation including bone marrow biopsy.

Table III (opposite) shows the distribution by age of the whole group, by sex and type of leukaemia. The well-recognized distribution pattern with preschool peak incidence is apparent, but the preponderance of males to females (63.6 per cent. : 36.4 per cent). 
is in excess of that obtained from the mortality figures for England and Wales (55.7 per cent.: 44.3 per cent. annual mean values for years 1959 63 for age groups $1-4$ and 5-14).

\section{TABLE III}

AGE DISTRIBUTION, SEX, AND TYPE OF LEUKAEMIA

\begin{tabular}{|c|c|c|c|c|c|c|}
\hline \multirow{2}{*}{$\begin{array}{l}\text { Age } \\
\text { (grs) }\end{array}$} & \multirow[b]{2}{*}{ Total } & \multicolumn{2}{|c|}{ Sex } & \multicolumn{3}{|c|}{ Type of Leukaemia } \\
\hline & & Male & Female & $\begin{array}{l}\text { Acute } \\
\text { Lympho- } \\
\text { blastic }\end{array}$ & $\begin{array}{l}\text { Acute } \\
\text { Myelo- } \\
\text { blastic }\end{array}$ & Other \\
\hline $\begin{array}{l}<1 \\
1-2\end{array}$ & $\begin{array}{l}3 \\
5\end{array}$ & 2 & $\frac{1}{2}$ & 2 & $\begin{array}{l}1 \\
1\end{array}$ & $\begin{array}{l}1 \text { Acute } \\
\text { Monocytic }\end{array}$ \\
\hline $\begin{array}{l}2-3 \\
3-4 \\
4-5 \\
5-6\end{array}$ & $\begin{array}{r}7 \\
4 \\
12 \\
6\end{array}$ & $\begin{array}{l}4 \\
3 \\
9 \\
3\end{array}$ & $\begin{array}{l}3 \\
1 \\
3 \\
3\end{array}$ & $\begin{array}{r}5 \\
3 \\
11 \\
2\end{array}$ & $\begin{array}{l}2 \\
1 \\
1 \\
3\end{array}$ & 1 Acute \\
\hline $\begin{array}{l}6-7 \\
7-8 \\
8-9\end{array}$ & $\begin{array}{r}10 \\
3 \\
5\end{array}$ & $\begin{array}{l}6 \\
2 \\
2\end{array}$ & $\begin{array}{l}4 \\
1 \\
3\end{array}$ & $\begin{array}{l}8 \\
2 \\
4\end{array}$ & $\begin{array}{l}2 \\
1 \\
0\end{array}$ & 1 Acute \\
\hline $\begin{array}{r}9-10 \\
10-11 \\
11-12\end{array}$ & $\begin{array}{l}2 \\
4 \\
5\end{array}$ & $\begin{array}{l}1 \\
3 \\
3\end{array}$ & $\begin{array}{l}1 \\
1 \\
2\end{array}$ & $\begin{array}{l}1 \\
4 \\
3\end{array}$ & $\begin{array}{l}1 \\
0 \\
1\end{array}$ & 1 Acute \\
\hline $\begin{array}{l}12-13 \\
13-14 \\
14-15\end{array}$ & $\begin{array}{l}3 \\
1 \\
4\end{array}$ & $\begin{array}{l}3 \\
0 \\
3\end{array}$ & $\begin{array}{l}0 \\
1 \\
1\end{array}$ & $\begin{array}{l}2 \\
0 \\
2\end{array}$ & $\begin{array}{l}1 \\
1 \\
2\end{array}$ & \\
\hline Total & 74 & 47 & 27 & 52 & 18 & 4 \\
\hline
\end{tabular}

Table IV shows the seasonal occurrence of the various types of leukaemia for all ages, subdivided by age group into under 5 years and 5 years and over. The only apparent difference in this series is a small increase in the number of cases of acute lymphoblastic leukaemia with summer onsets in the younger age group. $\chi^{2}$ testing gives $P>0.5$, however, and this impression is not statistically significant. The three cases of monocytic leukaemia all began in June, but no inference can be drawn from so few cases.

\section{TABLE IV}

SEASON OF ONSET, BY AGE AND TYPE OF LEUKKAEMIA

\begin{tabular}{|c|c|c|c|c|}
\hline Season & Type of Leukaemia & $0-<15$ & $0-<5$ & $5-<15$ \\
\hline \multirow[b]{2}{*}{$\begin{array}{l}\text { Winter } \\
\text { (November } \\
\text { to April) }\end{array}$} & All Leukaemias & 35 & 13 & 22 \\
\hline & $\begin{array}{l}\text { A.B.L. + A.L.L. } \\
\text { A.M.L. } \\
\text { Acute Monocytic } \\
\text { Acute Erythro- } \\
\text { leukaemia }\end{array}$ & $\begin{array}{r}23 \\
11 \\
0 \\
1\end{array}$ & $\begin{array}{l}9 \\
4 \\
0 \\
0\end{array}$ & $\begin{array}{r}14 \\
7 \\
0 \\
1\end{array}$ \\
\hline \multirow[b]{2}{*}{$\begin{array}{l}\text { Summer } \\
\text { (May } \\
\text { to } \\
\text { October) }\end{array}$} & All Leukaemias & 39 & 17 & 22 \\
\hline & $\begin{array}{l}\text { A.B.L. + A.L.L. } \\
\text { A.M.L. } \\
\text { Acute Monocytic }\end{array}$ & $\begin{array}{r}28 \\
8 \\
3\end{array}$ & $\begin{array}{r}12 \\
4 \\
1\end{array}$ & $\begin{array}{r}16 \\
4 \\
2\end{array}$ \\
\hline
\end{tabular}

In order to study the spatial distribution of cases and to determine whether certain areas contained excessive numbers of patients, the concentrations were calculated for each electoral ward of the city of Liverpool (Figure, overleaf). The estimated total populations in 1962 are listed in Table V, together with population density per acre $\left(1\right.$ acre $=4.047 \times 10^{-3}$ sq. $\mathrm{km}$.), the number of cases observed during the 10-year period, and the annual incidence per 100,000 total population (not population at risk, as these figures are not available). The overall annual incidence is $0.733 \pm 0.57$ per 100,000 total population among the electoral wards. The expected incidence for each ward has been calculated on the basis of even distribution proportional to population. In six wards the number observed is more than double that expected, but $\chi^{2}$ testing with 40 degrees of

TABle V

DISTRIBUTION OF CASES OF CHILDHOOD LEUKAEMIA IN LIVERPOOL, BY ELECTORAI WARDS, 1955-64

\begin{tabular}{|c|c|c|c|c|c|}
\hline \multirow{2}{*}{$\begin{array}{c}\text { Electoral } \\
\text { Ward }\end{array}$} & \multicolumn{2}{|c|}{ Population* } & \multicolumn{2}{|c|}{ No. of Cases } & \multirow{2}{*}{$\begin{array}{c}\text { Incidence } \\
\text { per } 100,000 \\
\text { Population } \\
\text { per Year }\end{array}$} \\
\hline & $\begin{array}{c}\text { Estimated } \\
\text { Total } \\
\text { (1962) }\end{array}$ & $\begin{array}{l}\text { Density } \\
\text { per Acre }\end{array}$ & Expected & Observed & \\
\hline $\begin{array}{l}\text { Abercromby } \\
\text { Aigburth } \\
\text { Allerton } \\
\text { Anfield } \\
\text { Arundel }\end{array}$ & $\begin{array}{l}14,680 \\
21,640 \\
15,910 \\
21,900 \\
19,860\end{array}$ & $\begin{array}{r}55.0 \\
18.5 \\
9.9 \\
40 \cdot 2 \\
39 \cdot 3\end{array}$ & $\begin{array}{l}1 \cdot 104 \\
1.627 \\
1.196 \\
1.645 \\
1.492\end{array}$ & $\begin{array}{l}\text { Nil } \\
1 \\
\text { Nil } \\
\text { Nil } \\
\text { Nil }\end{array}$ & $\begin{array}{l}0 \\
0 \cdot 46 \\
0 \\
0 \\
0\end{array}$ \\
\hline $\begin{array}{l}\text { Breckfield } \\
\text { Broadgreen } \\
\text { Central } \\
\text { Childwall } \\
\text { Church }\end{array}$ & $\begin{array}{l}17,170 \\
17,780 \\
10,740 \\
26,480 \\
21,280\end{array}$ & $\begin{array}{l}98 \cdot 1 \\
26 \cdot 6 \\
17 \cdot 3 \\
21 \cdot 3 \\
26 \cdot 7\end{array}$ & $\begin{array}{l}1.294 \\
1.337 \\
0.807 \\
1.99 \\
1.599\end{array}$ & $\begin{array}{c}1 \\
2 \\
\mathbf{N i l} \\
2 \\
2\end{array}$ & $\begin{array}{l}0.58 \\
1.12 \\
0 \\
0.75 \\
0.94\end{array}$ \\
\hline $\begin{array}{l}\text { Clubmoor } \\
\text { County } \\
\text { Croxteth } \\
\text { Dingle } \\
\text { Dovecot }\end{array}$ & $\begin{array}{l}17,560 \\
21,000 \\
18,220 \\
19,030 \\
22,420\end{array}$ & $\begin{array}{l}34.5 \\
48.6 \\
15.9 \\
53.7 \\
23.6\end{array}$ & $\begin{array}{l}1 \cdot 319 \\
1.578 \\
1 \cdot 370 \\
1.43 \\
1.685\end{array}$ & $\begin{array}{l}1 \\
1 \\
3 \\
1 \\
1\end{array}$ & $\begin{array}{l}0.57 \\
0.48 \\
1.65 \\
0.53 \\
0.45\end{array}$ \\
\hline $\begin{array}{l}\text { Everton } \\
\text { Fairfield } \\
\text { Fazakerley } \\
\text { Gillmoss } \\
\text { Granby }\end{array}$ & $\begin{array}{l}15,350 \\
21,150 \\
17,680 \\
24,980 \\
17,600\end{array}$ & $\begin{array}{l}70 \cdot 4 \\
34 \cdot 9 \\
23 \cdot 9 \\
13 \cdot 7 \\
92 \cdot 1\end{array}$ & $\begin{array}{l}1 \cdot 153 \\
1.59 \\
1.328 \\
1.877 \\
1 \cdot 322\end{array}$ & $\begin{array}{c}1 \\
1 \\
\text { Nil } \\
5 \\
\text { Nil }\end{array}$ & $\begin{array}{l}0.65 \\
0.47 \\
0 \\
2.02 \\
0\end{array}$ \\
\hline $\begin{array}{l}\text { Kensington } \\
\text { Low Hill } \\
\text { Melrose } \\
\text { Netherfield } \\
\text { Old Swan }\end{array}$ & $\begin{array}{l}18,690 \\
14,500 \\
14,550 \\
12,040 \\
22,980\end{array}$ & $\begin{array}{l}75 \cdot 3 \\
81 \cdot 0 \\
78 \cdot 6 \\
90 \cdot 5 \\
43 \cdot 2\end{array}$ & $\begin{array}{l}1.405 \\
1.09 \\
1.092 \\
0.894 \\
1.727\end{array}$ & $\begin{array}{l}1 \\
1 \\
1 \\
1 \\
2\end{array}$ & $\begin{array}{l}0.53 \\
0.69 \\
0.68 \\
0.47 \\
0.93\end{array}$ \\
\hline $\begin{array}{l}\text { Picton } \\
\text { Pirrie } \\
\text { Princes Park } \\
\text { St. Domingo } \\
\text { St. James }\end{array}$ & $\begin{array}{l}21,570 \\
25,730 \\
20,190 \\
18,320 \\
15,540\end{array}$ & $\begin{array}{r}57 \cdot 4 \\
20 \cdot 6 \\
69 \cdot 6 \\
102 \cdot 3 \\
22 \cdot 3\end{array}$ & $\begin{array}{l}1 \cdot 621 \\
1.933 \\
1.517 \\
1 \cdot 38 \\
1 \cdot 168\end{array}$ & $\begin{array}{l}1 \\
2 \\
2 \\
2 \\
3\end{array}$ & $\begin{array}{l}0.46 \\
0.78 \\
0.99 \\
1.09 \\
1.93\end{array}$ \\
\hline $\begin{array}{l}\text { St. Mary's } \\
\text { St. Michael's } \\
\text { Smithdown } \\
\text { Speke } \\
\text { Sandhills }\end{array}$ & $\begin{array}{l}17,040 \\
15,690 \\
18,370 \\
21,880 \\
12,400\end{array}$ & $\begin{array}{l}14 \cdot 0 \\
20 \cdot 4 \\
73 \cdot 8 \\
10 \cdot 2 \\
13 \cdot 4\end{array}$ & $\begin{array}{l}1 \cdot 28 \\
1.179 \\
1.38 \\
1.644 \\
0.932\end{array}$ & $\begin{array}{c}\text { Nil } \\
1 \\
2 \\
1 \\
\text { Nil }\end{array}$ & $\begin{array}{l}0 \\
0.64 \\
1.09 \\
0.46 \\
0\end{array}$ \\
\hline $\begin{array}{l}\text { Tuebrook } \\
\text { Vauxhall } \\
\text { Warbreck } \\
\text { Westminster } \\
\text { Woolton }\end{array}$ & $\begin{array}{l}19,690 \\
14,900 \\
19,820 \\
11,370 \\
27,530\end{array}$ & $\begin{array}{l}45.6 \\
73.4 \\
29.3 \\
80.6 \\
11.4\end{array}$ & $\begin{array}{l}1.48 \\
1.119 \\
1.489 \\
0.854 \\
2.068\end{array}$ & $\begin{array}{l}4 \\
3 \\
1 \\
4 \\
2\end{array}$ & $\begin{array}{l}2.03 \\
2.01 \\
0.53 \\
3 \cdot 52 \\
0.73\end{array}$ \\
\hline $\begin{array}{c}\text { Total C.B.C. } \\
\text { Liverpool }\end{array}$ & 745,230 & $26 \cdot 8$ & 56 & 56 & 0.733 \\
\hline
\end{tabular}

- The above population figures are derived from the figures in the Annual Report for 1962 of the Medical Officer of Health for Liverpool. 


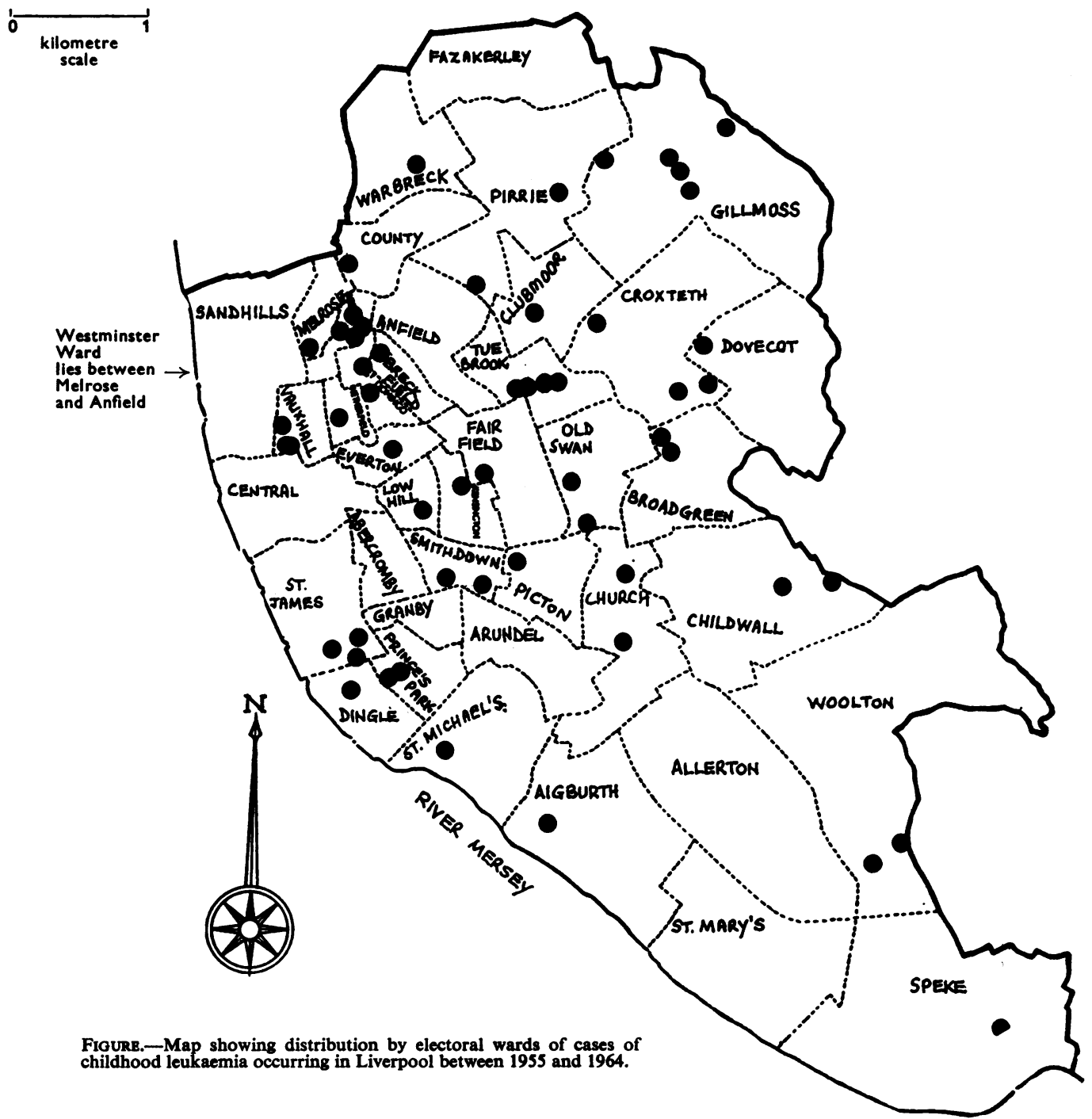

freedom does not give statistical confirmation of any significance as the numbers involved are small.

It is interesting that, of those wards with high incidence and low population density, Croxteth and Gillmoss are neighbouring wards consisting mainly of post-1920 housing development with comparatively large areas of open space-private parkland, playing fields, and a cemetery. St. James ward includes warehouses, docks, and other business premises which reduce the population density below the city mean, but the inhabitants tend to live in older terraced houses, many of which are overcrowded. Tuebrook, Vauxhall, and Westminster, the remaining wards with high incidence, are all areas in which most of the property is more than 50 years old and where overcrowding is common.

The data from all patients in the area were then analysed, using the computer technique first described by Knox in 1963, in order to investigate space-time relationships for possible clustering.

Dates of onset were converted to century day numbers. Six-figure grid references, as within square 
SJ of the National Grid, with easterly and northerly components, of which the least significant figures represent $0.1 \mathrm{~km}$., translated home addresses into numerical terms.

If all cases are compared with every other one 74 patients give 2,701 possible pairings. The time interval is obtained by subtraction of day numbers and distance apart by application of Pythagoras' theorem. In the first analysis, all cases were examined together, the allocation of pairs being seen in Table VIA. Cumulative frequencies are also shown in Table VIB, with + sign where a significant discrepancy (on the basis of $\chi^{2}$ test which is not necessarily reliable) has been found between the observed cumulative frequency and that calculated in direct proportion to row and column totals. The excess number of pairs appearing in the upper left corner of Table VIA, i.e. those with short time intervals and living short distances apart, is confirmed by the appearance of significant discrepancies in columns to the right and rows below in Table VIB.

The data were then divided into two groups by age. By chance, 37 patients were aged under 6 years, and 37 were aged 6 years and over. 666 possible pairs were produced in each group and analysed in the same way. Division of the group by age did not make the clustering tendency any more apparent.

\section{Discussion}

The ascertainment of cases of acute leukaemia occurring in children under the age of 15 is probably complete, as patients were in no way selected before referral, but rather were sent to one of the two children's hospitals, which serve the whole area, for initial diagnosis. The number found in Liverpool and the neighbouring areas during the period 1955-64 compares very closely with those calculated from the Registrar General's mortality figures for England and Wales. The national death rates per million per year from all types of leukaemia in children aged 0-14 were as follows (Court Brown and Doll, 1961):

$$
28 \text { in 1945-49 } 32 \cdot 5 \text { in } 1950-54 \quad 32 \cdot 5 \text { in 1955-59 }
$$

and for the age group 0-5

$$
42.9 \text { in } 1955-59
$$

The corresponding Liverpool figures for onsets of leukaemia are:

$$
\begin{aligned}
& 29 \cdot 8(1955-64) \text { per } 1,000,000 \text { aged } 0-14 \\
& 43 \cdot 2(1955-64) \text { per } 1,000,000 \text { aged } 0-4
\end{aligned}
$$

Hence there is no evidence that the incidence of the disease is different in this part of the Merseyside conurbation from elsewhere in England and Wales.

The seasonal variation in onset detected by Lee (1962) and found elsewhere in Great Britain (Knox, 1964) is not definite in this series, but the slight increase seen in the number of cases of acute lymphatic leukaemia starting in the summer accords with Lee's later findings (1963) that this type of the disease is the one responsible for the summer peak.

In order to determine whether cases were tending to occur more frequently in some parts of the area than others, the data were examined in two ways:

(1) The distribution of cases in the city of Liverpool divided by electoral wards showed higher incidence in six of the more densely populated

\begin{tabular}{|c|c|c|c|c|c|c|c|}
\hline \multirow{2}{*}{$\begin{array}{c}\text { 2,701 Possible } \\
\text { Pairs }\end{array}$} & \multirow{2}{*}{ Time (days) } & \multicolumn{6}{|c|}{ Distance (km.) } \\
\hline & & $0-2$ & -3 & -4 & -5 & -8 & All Distances \\
\hline \multirow[t]{2}{*}{$\begin{array}{c}\text { (A) } \\
\text { Times and } \\
\text { Distances } \\
\text { Apart }\end{array}$} & $\begin{array}{c}0-50 \\
-100 \\
-150 \\
-200 \\
-250 \\
-300 \\
-350 \\
-400 \\
-1,000\end{array}$ & $\begin{array}{r}6 \\
6 \\
11 \\
10 \\
11 \\
7 \\
6 \\
6 \\
59\end{array}$ & $\begin{array}{r}7 \\
6 \\
8 \\
9 \\
9 \\
7 \\
8 \\
4 \\
78\end{array}$ & $\begin{array}{r}11 \\
11 \\
7 \\
10 \\
12 \\
7 \\
9 \\
9 \\
93\end{array}$ & $\begin{array}{r}13 \\
8 \\
6 \\
8 \\
8 \\
7 \\
10 \\
11 \\
87\end{array}$ & $\begin{array}{r}16 \\
25 \\
12 \\
15 \\
25 \\
21 \\
21 \\
27 \\
215\end{array}$ & $\begin{array}{r}75 \\
71 \\
53 \\
73 \\
74 \\
66 \\
69 \\
77 \\
680\end{array}$ \\
\hline & All Times Apart & 263 & 253 & 328 & 338 & 835 & 2,701 \\
\hline \multirow[t]{2}{*}{$\begin{array}{c}\text { (B) } \\
\text { Cumulative } \\
\text { Frequencies }\end{array}$} & $\begin{array}{c}0-50 \\
-100 \\
-150 \\
-200 \\
-250 \\
-300 \\
-350 \\
-400 \\
-1,000\end{array}$ & $\begin{array}{r}6 \\
12 \\
23 \\
33 \\
44 \\
51 \\
57 \\
63 \\
122\end{array}$ & $\begin{array}{c}13 \\
25 \\
44 \\
63 \\
83+ \\
97+ \\
111+ \\
121+ \\
258\end{array}$ & $\begin{array}{c}24 \\
47 \\
73 \\
102 \\
134+ \\
155+ \\
178+ \\
197 \\
427\end{array}$ & $\begin{array}{l}37 \\
68 \\
100 \\
137 \\
177+ \\
209+ \\
242+ \\
272 \\
589\end{array}$ & $\begin{array}{r}53 \\
109 \\
153 \\
205 \\
270 \\
323 \\
377 \\
434 \\
976\end{array}$ & $\begin{array}{r}75 \\
146 \\
199 \\
272 \\
346 \\
412 \\
481 \\
558 \\
1,238\end{array}$ \\
\hline & All Times Apart & 263 & 516 & 844 & 1,182 & 2,017 & 2,701 \\
\hline
\end{tabular}
wards or parts of wards. The exact population of

TABLE VI (A AND B)

74 CASES OF ACUTE LEUKAEMIA IN LIVERPOOL 
children at risk in each ward is not known but, as the more densely populated areas of Liverpool tend to have higher birth rates, it is likely that the numbers actually at risk in these overcrowded parts are somewhat higher than proportions based on the figures for the whole city. Making allowance for this inaccuracy, there is still some suggestion that cases tended to occur preferentially in certain parts of the city although this is a difficult hypothesis to test and it did not prove possible to elicit positive significance tests.

(2) The data for the whole area were analysed by computer, as described previously, to detect any clustering in time and space. The results obtained show discrepancies from those to be expected if the cases had occurred at random. An excess number of pairs with short distances and short times apart was found in the analysis of the whole group. The highest levels of significance are centred on pairs with intervals less than $4 \mathrm{~km}$. and 300 days. This pattern of clustering is comparable with that found by Meighan and Knox (1965) when 69 cases under 15 years in Portland, Oregon, during 1950-61 were analysed by this method. Knox (1964) found a space-time interaction affecting lymphoblastic leukaemia of young children in Northumberland, Durham, and Teeside during 1951-60, which was maximal for pairs with intervals less than $1 \mathrm{~km}$. and less than 60 days. He also found a higher risk in children living in larger towns, the urban incidence being $47 \cdot 1$ per $1,000,000$ child-years aged 0-5. This may represent a slightly lower overall incidence than in Merseyside children, where the incidence of $43 \cdot 2$ per $1,000,000$ child-years refers to the higher risk age group $0-4$.

These results support those found in previous studies in which the same technique has been applied. It is important that similar analytic tools should be used for data from as many different areas as possible in order that valid comparisons may be made.

\section{SUMmaRY}

There were 74 cases of acute leukaemia in children under 15 years diagnosed between 1955 and 1964 in the Liverpool area. Seasonal variation was not found, but cases tended to occur in certain more densely populated areas. A clustering factor was detected by application of a computer technique, an excessive number of pairs separated by less than $4 \mathrm{~km}$. and 300 days being found.

I should like to express my thanks to Dr E. G. Knox, of the Department of Social Medicine, University of Birmingham, who kindly undertook the computer analysis of the data, and also for his helpful advice in the preparation of this report.

My thanks are also due to Dr S. E. Keidan, Consultant Paediatrician, Alder Hey Children's Hospital, Liverpool, under whose guidance this work was undertaken.

\section{REFERENCES}

Court Brown, W. M., and Doll, R. (1961). Brit. med. J., $1,981$.

David, F. N., and Barton, D. E. (1966). Brit. J. prev. soc. Med., $20,44$.

Grist, N. R., and Fallon, R. J. (1964). Brit. med. J., 2, 1263.

Heath, C. W., and Hasterlik, R. J. (1963). Amer. J. Med., 34, 796 .

Knox, G. (1963). Brit. J. prev. soc. Med., 17, 121.

(1964). Ibid., 18, 17.

Lee, J. A. H. (1962). Brit. med. J., 1, 1739. (1963). Ibid., $2,623$.

Meighan, S. S., and Knox, G. (1965). Cancer, 18, 811.

Miller, R. W. (1964). New Engl. J. Med., 271, 30.

Mustacchi, P. (1965). Cancer, 18, 362.

Negroni, G. (1964). Brit. med. J., 1, 927.

Pinkel, D., and Nefzger, D. (1959). Cancer, 12, 351.

Registrar General (1964a). "Statistical Review of England and Wales", Part I, Tables, Medical, pp. 133 and 46. H.M.S.O., London.

(1964b). Ibid., Part II, Tables, Population, pp. 29-33. H.M.S.O., London.

(1965). Ibid., Part III, Commentary, p. 137. H.M.S.O., London.

Wood, E. E. (1960). Brit. med.J., 1, 1760. 